The Chittagong Univ. J. B. Sci., Vol. 6(1 \&2):41-49, 2011.

\title{
GLUCOSE STATUS IN CEREBROSPINAL FLUID (CSF) IN DIFFERENT MENINGITIC CHILDREN IN A HOSPITAL IN CHITTAGONG, BANGLADESH.
}

\author{
SHARMISTHA MITRA ${ }^{1}$, ROBIUL HASAN BHUIYAN ${ }^{1}$, MD. ARIFUZZAMAN ${ }^{2}$, \\ MOHAMMAD SAYEDUL ISLAM ${ }^{1}$, MAHMOOD A CHOWDHURY ${ }^{3}$, MOHAMMAD \\ ALAUDDIN $^{1 *}$ \\ ${ }^{1}$ Department of Biochemistry and Molecular Biology, University of Chittagong, Chittagong-4331, \\ Bangladesh. \\ ${ }^{2}$ Department of Biochemistry and Biotechnology, University of Science \& Technology, \\ Chittagong, Bangladesh. \\ ${ }^{3}$ Department of Pediatrics Medicine, Chittagong Maa Shishu-O-General Hospital, Chittagong, \\ Bangladesh.
}

\begin{abstract}
Meningitis is referred to as an inflammatory process of the leptomeninges and cerebrospinal fluid (CSF) within the sub-arachnoid space of the brain. We have investigated glucose status in CSF in different types of meningitis together with detailed medical history in children. In addition, we have also carried out the detailed cytological and microbiological examinations. A total of 40 subjects were investigated. We observed that the glucose level was significantly decreased $(<20 \mathrm{mg} / \mathrm{dl})$ in $65 \%$, moderately decreased $(20-40 \mathrm{mg} / \mathrm{dl})$ in $20 \%$ and mildly decreased $(40-50 \mathrm{mg} / \mathrm{dl})$ in $15 \%$ of the patients in our study. Patients with Pyogenic meningitis had tremendously reduced glucose level $(9.0 \mathrm{mg} / \mathrm{dl})$ in their CSF whereas in viral meningitis the CSF glucose level is highly variable (10 to 65 $\mathrm{mg} / \mathrm{dl})$. Furthermore, 5 (12.5\%) patients showed high lymphocyte counts and 34 $(85 \%)$ patients showed high neutrophil counts. Interestingly, in Pyogenic meningitis, the neutrophil count was very high compared to that in viral meningitis. The present study clearly demonstrates that biochemical parameters such as glucose level in CSF might be a potential tool for detecting meningitis and as well as differentiation of the different types of meningitis.
\end{abstract}

Key words: Meningitis, Cerebrospinal fluid, Glucose, Pyogenic meningitis.

\section{INTRODUCTION}

Cerebrospinal fluid (CSF) is a clear, colorless watery fluid formed by the choroid plexus of the lateral ventricle and the third ventricle of the brain. Based on physical appearance of the CSF, the meningitis could be differentiated

*Corresponding Author:alauddin_bmb@yahoo.com 
into pyogenic (cloudy or hazy appearance), haemorrhagic (red/bloody appearance) and yellow color (xanthochromia) (Khaleque 1963). If the CSF is brown, orange or yellow, it may be a sign of increased CSF protein or previous bleeding (Arevalo et al. 1989) and could be associated with pyogenic meningitis and or tuberculous meningitis (Conly et al. 1983). Meningitis usually results from infection by microorganisms (Fortún et al. 1994). A critical event in the pathogenesis of bacterial meningitis is the inflammatory reaction induced by the invading bacteria. Many of the neurologic manifestations and complications of bacterial meningitis result from the host immune response to the invading pathogen rather than from direct bacteria-induced tissue injury (Lehnardt et al. 2007). As a result, neurologic injury can progress even after the CSF has been sterilized by antibiotic therapy (Tsubota et al. 2010). Viruses that can cause meningitis include enteroviruses, herpes simplex virus type 2, varicella zoster virus, mumps virus, HIV, and LCMV (Logan \& MacMahon 2008). Mild cases of viral meningitis can be treated at home with conservative measures such as fluid, bed rest and analgesics (Meningitis and Encephalitis Fact Sheet 2007).The diagnosis of meningitis is made by patients feature of meningism such as neck rigidity, Kernig's sign and Brudzinski's sign (Strachan et al. 2008). Diagnosis is also made by biochemical analysis of CSF and microbiological identification of bacteria in case of bacterial meningitis; either by bacterial culture or broad range PCR. However, in many cases in our country, microorganisms could not be isolated because of improper use of broad spectrum antibiotic therapy before the diagnosis is established. So biochemical analysis like CSF glucose, CSF protein might be important parameter to exclude the viral meningitis from bacterial meningitis. Low CSF glucose level usually is associated with bacterial infection both pyogenic and tuberculus. However, glucose level remains normal in case of viral meningitis (Abro et al. 2008). So, in this study, we have investigated glucose status in different type of meningitis.

\section{METHODS AND MATERIALS}

\section{Patient selection}

The study was conducted in the Pathology \& Microbiology laboratory, Chattagram Maa Shishu-O-General Hospital, Agrabad, Chittagong, Bangladesh during the period of November 2008 to June 2009. Forty subjects were included in this study. Informed parental consent was taken before enrolling the children into the study. The study subjects comprised of the following four groups: pyogenic-27 subjects with pyogenic meningitis, viral-5 subjects with viral 
GLUCOSE STATUS IN CEREBROSPINAL FLUID (CSF) IN DIFFERENT MENINGITIC

CHILDREN IN A HOSPITAL IN CHITTAGONG, BANGLADESH.

meningitis, tubercular-2 subjects with tubercular meningitis and normal-6 subjects were normal, healthy children. All subjects were enrolled everyday between 9:00 a.m. and 2:00 p.m. from the pediatric unit who were admitted into this hospital mainly with the complaints of fever. In all cases, the suspected meningitis subjects were between 0 and 12 years old. A questionnaire was developed to obtain relevant information of demographic and socio-economic data. The questionnaire also included anthropometric data, birth history, immunization history, past medical history and clinical information.

\section{CSF Collection}

CSF was collected from the selected patients by the process of lumbar puncture (usually in the space between third and fourth lumbar vertebra) done in the hospital ward with a sterile lumbar puncture needle and stilette with 3 sterile glass vials (one for biochemical, one for cytological and one for microbiological study). $10 \mathrm{ml}$ fluid was collected in each vial, which were sent to laboratory after proper labeling.

\section{Estimation of CSF Glucose}

Estimation of glucose level was done by Glucose oxidase method. Freshly collected CSFs were first centrifuged to remove blood cells and particles. Three test tubes were taken and marked them as blank, sample and standard. Ten $\mu l$ of sample was taken in sample test tube, $10 \mu \mathrm{l}$ standard in standard test tube and $10 \mu \mathrm{l}$ purified water was taken in blank test tube. After adding $1000 \mu \mathrm{l}$ reagent in all test tubes, it was mixed thoroughly and kept at room temperature for 10 minutes. Absorbance of the sample and standard were measured at $546 \mathrm{~nm}$ after adjusting the blank as zero.

\section{Calculation}

$\triangle$ Abs. of sample $X$ standard conc. $=$ Glucose conc. $(\mathrm{mg} / \mathrm{dl})($ Bablok et al. 1988).

$\triangle$ Abs. of standard

\section{Microbiological examination}

With all aseptic measures, an aliquot of the CSF was plated on LB agar (Lysogeny Broth) plate and incubated at $37^{\mathrm{O}} \mathrm{C}$ for overnight. The presence or absence of organism was detected based on appearance of colonies and colony morphologies. 


\section{Cell counting in the CSF}

Neutrophil and lymphocyte counts were done by spreading a drop of CSF on a microscope slide. The slide was stained with a Giemsa stain and examined under a microscope at 100X. The neutrophils and lymphocytes were identified based on the shape and appearance of the nucleus and the presence and color of the granules. The neutrophils had granules and polymorphic nucleus. On the other hand lymphocytes had no granules and no polymorphic nucleus, but only a single nucleus.

\section{RESULTS AND DISCUSSIONS}

The analysis of the cerebrospinal fluid (CSF) changes in acute meningitis could be good means of discriminating bacterial and viral meningitis in children (Abro et al. 2008). The meningitis patients admitted to Chattagram Maa Shishu-O-General Hospital for Infectious Diseases in Chittagong from November 2008-June 2009, with the sign and symptoms of meningitis such as headache, nausea, vomiting, fever, restlessness, irritability, neck pain, poor feeding, neck rigidity, Kernig's sign, Brudzinski's sign, Bulged Fontanels (Table 1 and 2) were included in this study. The study was designed based on the detailed background data of the patients (previous records of infectious diseases/illness, vaccination, socio-economic status) and detailed clinical, immunological and biochemical examinations of their cerebrospinal fluid. The risk factors and side effects were determined by different parameters such as socio-economic condition of the patients attending at Chattagram Maa Shishu-OGeneral Hospital, Chittagong, Bangladesh.

TABLE 1: SYMPTOMS OF THE PATIENTS IN THIS STUDY.

\begin{tabular}{cccc}
\hline No. of patients & Symptom & Present $(\%)$ & Absent (\%) \\
\hline \multirow{3}{*}{40} & Headache & 37.5 & 62.5 \\
& Vomiting & 80 & 20 \\
& Blurring of vision & 85 & 15 \\
& Convulsion & 65 & 35 \\
\hline
\end{tabular}


GLUCOSE STATUS IN CEREBROSPINAL FLUID (CSF) IN DIFFERENT MENINGITIC

CHILDREN IN A HOSPITAL IN CHITTAGONG, BANGLADESH.

\section{TABLE 2: NERVOUS SYSTEM EXAMINATIONS OF THE PATIENTS} INCLUDED IN THIS STUDY.

\begin{tabular}{ccccc}
\hline $\begin{array}{c}\text { No. of } \\
\text { patients }\end{array}$ & $\begin{array}{c}\text { Neck } \\
\text { rigidity }\end{array}$ & $\begin{array}{c}\text { Kernig's } \\
\text { sign }\end{array}$ & $\begin{array}{c}\text { Brudziniski's } \\
\text { sign }\end{array}$ & $\begin{array}{c}\text { Bulged } \\
\text { Fontanels }\end{array}$ \\
\hline 40 & $30(75 \%)$ & $22(55 \%)$ & $24(60 \%)$ & $34(85 \%)$ \\
\hline
\end{tabular}

In terms of socio-economic status, the distribution of the patients were upper class (15\%), middle class (30\%) and lower class (55\%), indicating that though the disease can affect peoples regardless of their socio-economic status, lower economic class peoples are more susceptible to meningitis (data not shown). Moreover, most of the patients that exhibited the sign and symptoms of meningitis had the following symptoms: vomiting (80\%), headache (37.5\%), convulsion (65\%) (Table 1). We also observed that meningitis could occur even in those who were vaccinated (Data not shown).

The micobiological studies revealed the presence of Diplococci and Gram (-ve) Bacilli in $6(15 \%)$ and $2(5 \%)$ patients, while no microbial pathogens were detected in the rest $32(80 \%)$ patients (Fig: 3 ). The absence of any microbial pathogens in the rest 32 patients CSF could be due to the fact that from the very onset of the disease, those patients were treated with antibiotics. But the changes of physiological appearance in their CSF were suggestive of bacterial meningitis (Table 3). These observations greatly deviated from a previous observation. However, it showed some similarities (Hussein and Shafran 2000).

Differential diagnosis between viral and bacterial meningitis is very difficult. Most of the patients of both bacterial and viral meningitis shared common features of meningism; Neck rigidity 30 (75\%), Kernig's sign $22(55 \%)$, Brudziniski sign 24 (60\%), Bulged Fontanels 34 (85\%). Bulged Fontanels was present in $85 \%$ patients (Table 2), which is clearly in line with a previous study (Abro et al. 2008).

It is well reported that all forms of pyogenic meningitis are frequently associated with leucocytosis and a raised ESR (erythrocyte sedimentation rate) and viral meningitis is associated with high lymphocyte count, though in a few cases lymphocyte count were found normal. In our study, we observed high lymphocyte count in $5(13 \%)$ patients and high polymorphs count in 32 (84\%) patients (Fig: 2), which supported the results of Negrini (Negrini et al. 2000). They showed that the CSF leukocyte count was higher with predominant 
polymorphs $(95 \%)$ in bacterial than viral $(7 \%)$ cases. Most of the patients with aseptic meningitis had neutrophils accounted for $>50 \%$ of CSF leukocytes (Negrini et al. 2000).

TABLE 3: PHYSICAL APPEARANCE OF CSF COLLECTED PATIENTS INCLUDED IN THIS STUDY.

\begin{tabular}{cccc}
\hline No. of patients & Hazy & Clear & Straw \\
\hline 40 & 24 & 6 & 10 \\
\hline
\end{tabular}

TABLE 4: EFFECT OF CSF GLUCOSE LEVEL IRRESPECTIVE OF MICROORGANISM PRESENT AND ABSENT.

\begin{tabular}{c|c|c|c}
\hline No. of patients & Micro-organisms & $\begin{array}{c}\text { Glucose Level } \\
(\text { Mean } \pm \text { SD })\end{array}$ & P* \\
\hline \multirow{2}{*}{40} & Present (8) & $11.75 \pm 2.52(\mathrm{mg} / \mathrm{dl})$ & \\
& Absent (32) & $24.54 \pm 12.59(\mathrm{mg} / \mathrm{dl})$ & 0.007 \\
\hline
\end{tabular}

*Student $\mathrm{T}$ test was done for the test of significance.

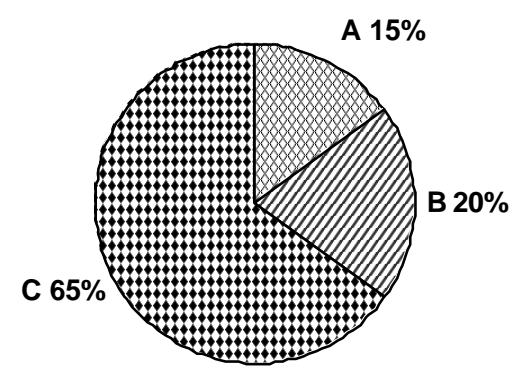

FIGURE 1: GLUCOSE LEVELS (A) MILDLY DECREASED (40-50 mg/dl) (B) MODERATELY DECREASED $(20-40 \mathrm{mg} / \mathrm{dl})$ \& (C) MASSIVELY DECREASED $(<20 \mathrm{mg} / \mathrm{dl})$. 
GLUCOSE STATUS IN CEREBROSPINAL FLUID (CSF) IN DIFFERENT MENINGITIC

CHILDREN IN A HOSPITAL IN CHITTAGONG, BANGLADESH.

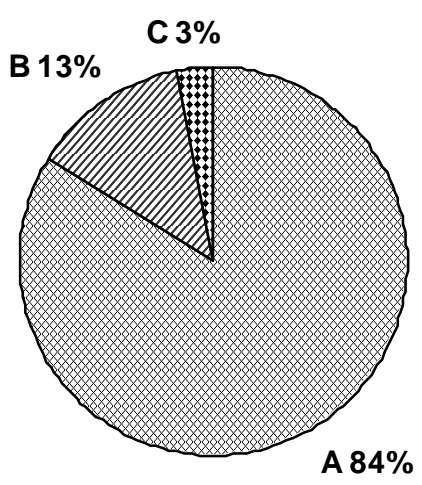

FIGURE 2: NEUTROPHILS, LYMPHOCYTES AND OTHERS (A) 84\% OF NEUTROPHIL (B) 13\% OF LYMPHOCYTES \& (C) OTHERS.

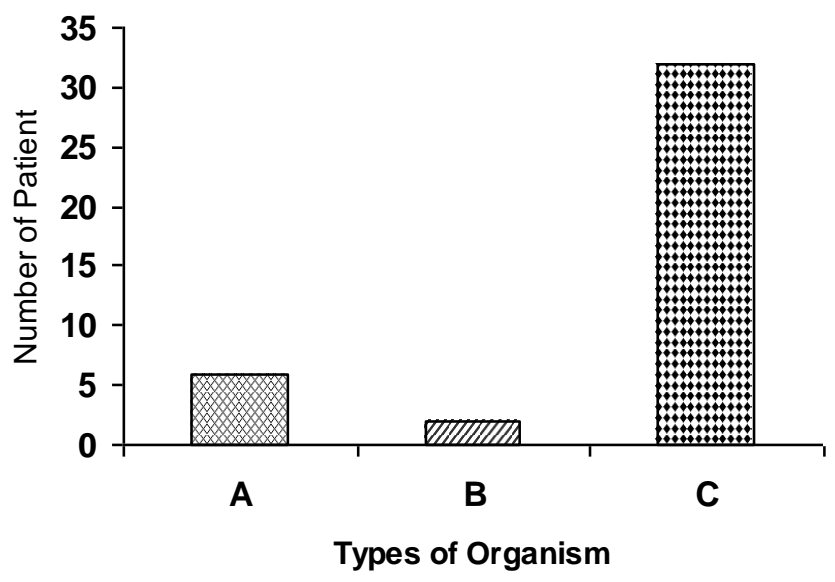

FIGURE 3: NUMBER AND TYPES OF ORGANISMS. (A) PRESENCE OF GRAM+(VE) BACTERIA (B) PRESENCE OF GRAM-(VE) BACTERIA AND (C) ORGANISM NOT FOUND. 
The normal CSF glucose level of 45-85 mg/dl was reported (Panda and Dash 2002). In our study, we found that glucose content in CSF was significantly decreased in $26(65 \%)$ while moderately and mildly decreased in $8(20 \%)$ and 6 (15\%) of the patients, respectively (Fig: 1). More specifically, glucose level of $11.75 \pm 2.52 \mathrm{mg} / \mathrm{dl}($ Mean $\pm \mathrm{SD})$ was observed in the bacterial meningitic group which was significantly $(\mathrm{P}=0.007)$ different with glucose level of $24.54 \pm 12.59 \mathrm{mg} / \mathrm{dl}($ Mean \pm SD) in the nonbacterial meningitic group (Table 4). Similar observations have also been reported by other (Zeni et al. 1994 and Bender et al. 2010). These observations thus clearly indicate that glucose content in the CSF could be a good parameter for differentiating the bacterial meningitis and organism absent meningitis.

In this study, complete medical history of the patients, microbiological/cytological and detailed biochemical examination of the CSF of meningitis patients helped in a more accurate discrimination of different meningitis in children. In most cases in our country, meningitis suspected subjects bearing the common symptoms of meningitis are treated without considering the different types. Our result clearly demonstrated that the glucose status of the CSF can be an indication of the types of the different meningitis which ultimately could facilitate the disease management more precisely and could avoid unnecessary administration of antibiotics.

\section{REFERENCES}

ABRO, A.H., ABDOU, A.S., ALI, H., USTADI, A.M. AND HASAB, A.A.H. 2008. Cerebrospinal fluid analysis: acute bacterial verses viral meningitis. Pak. J. Med. Sci. 24(5):645-650.

AREVALO, C.E., BARNES, P.F., DUDA, M., LEEDOM, J.M. 1989. Cerebrospinal fluid cell counts and chemistries in bacterial meningitis. South Med. J. 82(9):1122-7.

BABLOK, W., PASSING, H., BENDER, R. AND SCHNEIDER,. B. 1988. A general regression procedure for method transformation. J. Clin. Chem. Clin. Biochem. 26(11):783-790.

BENDER, J.M., AMPOFO, K., BYINGTON, C.L., GRINSELL, M., KORGENSKI, K., DALY, J.A., MASON, E.O. AND PAVIA, A.T. 2010. Epidemiology of Streptococcus pneumoniae-induced hemolytic uremic syndrome in Utah children. Pediatr. Infect. Dis. J. 29(8):712-716.

CONLY, J.M. AND RONALD, A.R. 1983. Cerebrospinal fluid as a diagnostic body fluid. Am. J. Med. 75(1B):102-108. 
GLUCOSE STATUS IN CEREBROSPINAL FLUID (CSF) IN DIFFERENT MENINGITIC

CHILDREN IN A HOSPITAL IN CHITTAGONG, BANGLADESH.

FORTÚN, J., GÓMEZ-MAMPASO, E., NAVAS, E., HERMIDA, J.M., ANTELA, A. AND GUERRERO, A. 1994. Tuberculous meningitis caused by resistant microorganisms. Therapeutic failure in 2 patients with HIV infection and disseminated tuberculosis. Enferm. Infecc. Microbiol Clin. 12(3): 150-153.

HUSSEIN, A.S. AND SHAFRAN, S.D. 2000. Acute bacterial meningitis in adults: a 12-year review. Medicine (Baltimore). 79:360-368.

KHALEQUE, K.A. 1963. Practical Pathology, Third edition, Mrs. K. A.Samad Publishing. Dacca, East Pakistan; 351 pp.

LEHNARDT, S., WENNEKAMP, J., FREYER, D., LIEDTKE, C., KRUEGER, C., NITSCH, R., BECHMANN, I., WEBER, J. R. AND HENNEKE, P. 2007. TLR2 and caspase- 8 are essential for group B Streptococcusinduced apoptosis in microglia. The Journal of Immunology.179(9): 61346143.

LOGAN, S.A. AND MACMAHON, E. 2008. Viral meningitis. BMJ (Clinical research ed.) 336(7634): 36-40.

MENINGITIS AND ENCEPHALITIS FACT SHEET. 2007. National Institute of Neurological Disorders and Stroke (NINDS):12-11.

NEGRINI, B., KELLEHER, K.J. AND WALD, E.R. 2000. Cerebrospinal fluid findings in aseptic versus bacterial meningitis. Pediatrics. 105(2):316-319.

TSUBOTA, Y., OGAWA, T., OYANAGI, J., NAGASHIMA, Y. AND

MIYAZAKI, K. 2010. Expression of laminin gamma 2 chain monomer enhances invasive growth of human carcinoma cells in vivo. Int. J. Cancer. 127(9):2031-41.

PANDA, U.N. AND DASH, P.K. 2002. Current Medical Diagnosis and Treatment.Taypee Brothers Medical Publishers (P) Limited. New Delhi, India. $972 \mathrm{pp}$.

ZENI, F., VILLON, A. AND ASSICOT, M. 1994. Procalcitonin serum concentrations and severity of sepsis. Clin Intensive Care. 5(suppl 5):2.

Manuscript received on 23.01.2011; Accepted on 07.07.2012

The Chittagong University Journal of Biological Sciences, Vol. 6 (1 \& 2). Page No. 